\title{
Impact of Stem Integrated Argumentation-Based Inquiry Applications on Students ' Academic Success, Reflective Thinking and Creative Thinking Skills
}

\author{
Funda Yesildag-Hasancebi* \\ Science Education, Faculty of Education, Giresun University, Giresun,Turkey \\ ORCID: 0000-0001-9365-940X \\ Omer Guner \\ Science Education, Faculty of Education, Giresun University, Giresun,Turkey \\ ORCID: 0000-0001-8109-726X \\ Cagla Kutru \\ Science Education, Faculty of Education, Giresun University, Giresun,Turkey \\ ORCID: 0000-0002-5373-6172 \\ Mehmet Hasancebi \\ Science Teacher, Ministry of Education, Giresun Turkey \\ ORCID: 0000-0002-2770-8346
}

Article history

\section{Received:}

12.01.2021

Received in revised form: 12.04.2021

Accepted:

23.04.2021

Key words:

Argumentation-based inquiry, STEM, STEM-supported argumentation, Reflective thinking, Scientific creativity, Academic success, Science education
The purpose of the study is to determine the effect of argumentationbased inquiry approach (ABI) and STEM-supported ABI approach on students' academic achievement, scientific creativity and reflective thinking skills for problem solving, and to determine students' views about the process. Explanatory sequential design, one of the mixed research methods, was used in the study. A total of 41 students $(\mathrm{N}=20$ boys, $n=21$ girls) studying in the seventh grade of a secondary school in north-east Turkey constitute the study group. In the study, the two classes that the same teacher attended was randomly determined where one was an ABI group $(\mathrm{N}=21)$ and the other a STEM-supported ABI group $(\mathrm{N}=20)$. The groups worked with the same teacher throughout the study. In the quantitative dimension of the study, Academic Achievement Test, Reflective Thinking Scale for Problem Solving, and Scientific Creativity Scale was used, while semi-structured interview form was used in the qualitative dimension. Independent Groups T Test and ANCOVA were applied in the analysis of quantitative data. Content analysis was performed in the analysis of qualitative data. In the research, it was concluded that students' reflective thinking skills for problem solving, scientific creativity and academic success are more developed in applications made by integrating STEM into the ABI approach.

\footnotetext{
*Correspondency: funda.hasancebi@giresun.edu.tr
} 


\section{Introduction}

People need to keep up with the rapid change of information and technology in the 21st century that we live in (Aydın, Saka, \& Guzey, 2017; Robinson, 2003). Looking at the studies carried out, it seems that the current education system in the era in which we live is not enough to meet the needs of the era and keep up with future changes (National Research Council [NRC], 2011). At the point of training qualified people, there is a need for individuals who can keep up with changes, learn throughout their life and have a say in their professional lives (Başar, 2018; Ertek, Ertek \& Güneş, 2013; Gündüz \& Odabaş1, 2004; İşman \& Gürgün, 2008; Tezci \& Gürol, 2002; Yamak, Bulut \& Dündar, 2014). In particular, it has become an important requirement that a skill acquired in one field can be transferred to another (National Science Board [NSB], 2007).

Countries should train qualified people in order to have a say in both scientific and economic fields and to meet future changes, developments and needs (Stohlmann, Moore, \& Roehring, 2012; Şahin, Ayar \& Adigüzel, 2014; Tunkham, Donpudsa \& Dornbundit, 2016; TÜSİAD, 2017). As a matter of fact, the way to achieve this has made it necessary to reorganize the understanding of the education system in the first place. One of the important steps of this attempt is enhancing the orientation towards gaining higher-level thinking skills rather than gaining lower-level thinking skills (Leou, Abder, Riordon \& Zoller, 2006; Zoller, 1993).In this sense, when looking at the studies conducted, the argumentation method (Aydin \& Kaptan, 2014; Cengiz \& Kabapınar, 2017; Duru, Demir, Önen, \& Similar, 2011; Ecevit \& Kaptan, 2019; Erenler, 2017; Namdar \& Salih, 2017; Şensoy \& Aydoğdu, 2008; Özdem, Ertepınar, Çakıroğlu \& Erduran, 2013; Şen, Yılmaz \& Erdoğan, 2016) and STEM education approach in science education for the development of 21st century skills was determined to be highly effective (Akgündüz et. al., 2015; Dejarnette, 2012; Daugherty, 2012; Çorlu, 2014). This research focuses on the impact of the argumentation and STEM education approach on reflective thinking and creative thinking skills of the 21 st century skills via science education.

\section{Science education and argumentation}

With the 21st century, as countries adopt a modern understanding of education, it becomes clear that students should be at the forefront of the educational process and actively participate in courses during the process (Namdar \& Salih, 2017). Our country's i.e., Turkish education system also aims to create educational environments that will allow students to configure knowledge instead of taking information as it is like the case with the program of science course teaching, which aims to educate students as a science literate individual (Ministry of National Education [MoNE], 2018, 2013). In the program, it is mentioned that as part of a research-inquiry process, the student should be able to produce explanations and arguments in the process, rather than simply adopting the discovery process and conducting experiments (MoNE, 2018). An argument is a social activity created individually or as a group throughout thinking and writing, suggesting reasons related to an event or situation, and convincing by providing appropriate evidence (Driver, Newton \& Osborne, 2000). Argumentation, on the other hand, is to produce a claim based on the available data and to exchange ideas and put forward justifications to make people accept the validity of this claim. It can also be defined as a process in which the claim is revised based on criticizing, supporting and refuting the counter-claim (Berland \& Reiser, 2011; Driver, Newton \& Osborne, 2000; Toulmin \& Quan, 2000). Based on these concepts, the argumentation-based inquiry (ABI) method is a learning method designed to help students' structure scientific knowledge in scientific inquiry (Cavagnetto, Hand \& Norton-Meier, 2010; Hand \& Keys, 1999). ABI includes argumentation, scientific thinking, writing and discussion processes that 
support students' scientific discussions (Baydas, Yesildag-Hasancebi \& Kilis, 2018; Hand \& Norton-Meier, 2011).

When the studies in the literature are examined, it is seen that the method of argumentation increases academic success for Science Education. It contributes positively to the development of 21 st century and problem solving skills, ensures that science topics are learned in a meaningful and permanent way. By developing communication skills, it is suggested that method of argumentation also develops the ability to reason scientifically, as well as strengthening speech and writing in a scientific language (Çınar, 2013; Hasançebi, 2014; Hiğde \& Aktamış 2015; Kardaş, 2013). It is also among the findings that argumentation is effective in developing a positive attitude towards science education (Aydoğdu, 2017; Erdoğan, 2010; İşikar, 2017; Kaya, 2018; Osborne, Simon \& Collins, 2003; Tekeli 2009; Walker, et. al. 2012).

When the studies in the literature are examined, it would be fair to say that the argumentation method increases academic achievement in science education, contributes positively to the development of 21 st century skills and problem-solving skills, ensures that science topics are learned in a meaningful and permanent way, improves communication skills, strengthens speaking in a scientific language, and it can also be said that it improves the ability to talk (Çınar, 2013; Hiğde \& Aktamış, 2015; Kardaş, 2013; Yesildag-Hasançebi \& Gunel, 2014). It was also determined that argumentation is effective in developing a positive attitude towards science (Aydoğdu, 2017; Erdoğan, 2010; İşikar, 2017; Kaya, 2018; Osborne, Simon \& Collins, 2003; Tekeli 2009; Walker, et. al. 2012).

\section{Science education and STEM}

In order to equip individuals with 21st century skills in Science Education, the STEM approach has an important place as well as the argumentation method. In the research conducted, the emphasis is placed on the education of individuals with STEM approach to ensure that countries are economically advantageous in the future, to produce new ideas that will meet the requirements of the 21 st century and to follow existing developments and to not to lag behind these developments (Aygen, 2018; Eroğlu \& Bektaş, 2016; Korkmaz, Çakır \& Uğur Erdoğmuş, 2021; Kuvaç, 2018; Orpwood, Schmidt \& Jun, 2012; Yavuz, Hasancebi \& Yesildag-Hasancebi, 2020). STEM education, although it does not have a precise and clear definition, is an approach that emerges as a result of the integration of Science, Technology, Engineering and Mathematics (Dugger, 2010; Gülen \& Yaman, 2018; Scott, 2009; Zhou, 2010). The aim of STEM education is to train scientifically strong and qualified people who can survive in global competition, and to ensure that learning takes place within the disciplines of Science, Technology, Engineering and Mathematics (Aydın, Saka \& Guzey, 2017; National Academy of Engineering [NAE] and National Research Council [NRC], 2009). The knowledge is aimed to be gained holistically with the integration of these disciplines (Aranda, Lie \& Guzey, 2020). Interdisciplinary interaction is a situation where multiple disciplines are dealt with together under a single theme in the direction of a common problem (Webb, 2013). This integrated space collaboration through context or content can provide many advantages in terms of both knowledge and skill, especially when organized around an engineering design process (Moore \& Smith, 2014). For example, students who study STEM gain skills such as self-control, entrepreneurship, socialization, and collaborative work (Bodner \& Elmas, 2020; Moore, Guzey \& Brown, 2014) asthe individual uses many disciplines to effectively design, manage and produce the process leading to the solution of 
the problem (Moore \& Smith, 2014). Science education indeed provides an opportunity for this process to take place as desired.

Elmas and Gül (2020), who evaluated the science course curriculum in terms of its goals, teaching approach, achievements, roles of the teacher and student in terms of the applicability of the STEM education approach, noted that the achievements in the program are especially focused on the ability to design. Based on these achievements, which coincide with only one of the steps of the engineering design process and have a serious weight in the program, it may not be an appropriate approach to expect all teachers to develop and implement activities for the engineering design process (Margot \& Kettler, 2019; Radloff \& Guzey, 2016). Because students exposed to integrated STEM education approach are expected to gain abilities and skills such as creative thinking, problem solving, and decision making (Roberts, 2012). Therefore, it may be beneficial to consider the STEM approach together with other approaches or methods in order to increase or strengthen the effect it brings to the learning environment.

\section{Creative and reflective thinking skills in science education}

Creative and reflective thinking skills, one of the skills of the 21st century, have an important place in the context of the requirements of the age. A person who can think creatively allows society to move forward, pave the way for new inventions and solve problems creatively (Senemoğlu, 1996). Everything that people do in a specific time period is actually the product of unlimited creativity (Orhon, 2011). That is why people who have the ability to think creatively today and in the future are needed. İşleten and Küçük (2013) points out that the education system should be organized in such a way that people can reveal aspects of creativity, it also needs to provide opportunities for them to develop their creativity, and hence meet the requirements of the age. For these reasons, developing creative thinking skills is seen as an important goal in all education levels (Deniş \& Balım, 2012).

A person who can think reflectively, on the other hand, seeks to find different solutions to the problems he encounters with the enrichment of his mental life and realizes that his own perspective is enriched (Güvenç, 2012). Indeed, reflective thinking is important for science education as it is a skill that can help to reveal implicit learning habits and develop high-level thinking skills such as critical thinking, develop strategies for the encountered problems alongside a technical improvement process for the work done (Kızılkaya \& Aşkar, 2009). As a matter of fact, creative thinking and reflective thinking are among the skills that are intended to be acquired by students in the natural sciences curriculum in Turkey (MoNE, 2013; 2018).

Current education programs emphasize that the information given to the student should not be taken as it is by the students. Students are expected to absorb the information by interpreting the information presented to them via filtering it to ensure it caters to themselves (Dilci \& Babacan, 2012). In the science education program, it is aimed for students to associate contradictory situations related to problems they encounter in daily life and to think creatively, reflectively and critically over social problems (MoNE, 2018). It is thought that science education will contribute to the acquisition of these skills. The impact of ABI and STEM approaches, which are contemporary approaches to education, on the teaching process through science education, is the focus of this research. In the literature, there is no study in which STEM education is constructed with an argumentation approach. Therefore, this research is expected to contribute to the literature on how STEM education can be carried out 
with the argumentation process with its results. In addition, this research can give researchers an idea about the integration of STEM approach with different methods and approaches. In this context, the purpose of the study is to determine the effect of argumentation-based inquiry approach (ABI) and STEM-supported ABI approach on students' scientific creativity, academic achievement and reflective thinking skills for problem solving, and to determine students' views about the process. Research questions are thence as follows:

(1) How do ABI and STEM supported ABI approach affect students' scientific creativity?

(2) How do ABI and STEM-supported ABI approach affect students' academic success?

(3) How do ABI and STEM supported ABI approach affect students' reflective thinking skills for problem solving?

(4) What are the students' opinions about ABI and STEM supported ABI approach?

\section{Method}

\section{Research design}

Explanatory sequential design, one of the mixed research methods, was used in the study. Mixed research involves collecting qualitative and quantitative data about the facts with the same basis in one or more studies, and then analyzing and interpreting those data (Leech \& Onwuegbuzie, 2007). Explanatory sequential design is a research design that takes place in two different interactive stages (quantitative and qualitative), starting with the collection and analysis of quantitative data, and in which the results obtained at this stage are tried to be explained by collecting and analyzing qualitative data in the second stage (Creswell \& Plano-Clark, 2014). Quantitative data (achievement test and scales) were collected at the beginning and end of the study. At the end of the research, qualitative data (semi-structured interviews) were used to support quantitative data.

\section{Study group}

A total of 41 students ( $\mathrm{N}=20$ boys, $\mathrm{N}=21$ girls) studying in the seventh grade of a secondary school in north-east Turkey constitute the study group. Purposeful sampling method was used in determining the study group. Purposeful sampling allows in-depth study of situations where rich information is thought to be present (Yıldırım \& Şimşek, 2000). The reason of choosing purposeful sampling method is that the science teacher of the students with whom the application was carried out received in-service training on ABI and STEM education and is experienced in applying these methods in the class. The study groups consisted of two classes. The two classes that the same teacher attended was randomly determined where one was an $\mathrm{ABI}$ group $(\mathrm{N}=21)$ and the other a STEM-supported ABI group $(\mathrm{N}=20)$. The difference between the two groups was the teaching method applied in the lesson. Since the Turkish education system has a spiral structure MoNE (2018), the study groups have general knowledge about "Resultant Force" and "Movement with Constant Speed" from the unit "Force and Motion". However, the students in the "Force and Energy" unit did not have any previous knowledge about the information required and were informed within the scope of the study. The students participating in this study have not previously participated in an activity on ABI and STEM education approach.

\section{Data collection tools}

In the quantitative dimension of the study, Academic Achievement Test, Reflective Thinking Scale for Problem Solving, and Scientific Creativity Scale were used, while a semi- 
structured interview form was used in the qualitative dimension. Detailed information on the data collection tools used is given below.

\section{Academic achievement test}

The academic achievement test used in the research consists of questions selected from the academic achievement tests developed by Aktaş (2017), Öztürk (2019) and Gazibeyoğlu (2018) for the seventh grade "Force and Energy" unit, taking the validity of the scope into account. There are 27 multiple choice questions in the achievement test.

\section{Reflective thinking scale for problem solving}

This scale was prepared with the aim of measuring students' reflective thinking ability to solve problems related to force and energy. The scale was used by obtaining the necessary permissions from Kizılkaya and Ashkar (2009). The scale consists of three dimensions: reasoning, inquiry and evaluation. There are a total of 14 items in the scale: 4 in the reasoning dimension, 5 in the inquiry dimension and 5 in the evaluation dimension. The scale is of the likert type of 5 (never, rarely, sometimes, most of the time and always). The magnitude of the score taken from the scale is interpreted as the degree of having reflective thinking skills (Kızılkaya \& Ashkar, 2009).

\section{Scientific creativity scale}

In the study, the scientific creativity scale (SCS) developed by Hu and Adey (2002) was used to determine the level of scientific creativity of candidate teachers. SCS is important because it allows the evaluation of process, feature and product dimensions, which are the lower dimensions of scientific creativity. The lower dimensions of SCS have been translated into Turkish by Kadayifçi (2008) and Deniş-Çeliker and Balım (2012). The scale consists of seven open-ended questions about product development, unusual uses, scientific images, problem exploration, problem solving, product design, and science experimentation. The answers given to the questions were evaluated in terms of fluency, flexibility and originality, which are sub-dimensions of creativity. Fluency here is related to each of the answers to the questions, and the more responses produced, the greater the fluency. Flexibility is the application of given answers to different situations. For this, the answers are divided into categories, and each category shows flexibility. Originality on the other hand means the different answers given in the group.

\section{Semi-structured interview form}

A semi-structured interview form prepared in relation to the application process was applied to the student group, where argumentation and STEM-supported argumentation applications were performed. Examples of the questions in the interview are as follows: "How do you describe your activities in Science? What were the positive and negative skills that these activities developed in you? Did your activities affect your creativity? If yes, how?"

\section{Application process}

In the study, the two classes that the same teacher attended was randomly determined where one was an ABI group and the other a STEM-supported ABI group. After the pre-tests were applied to the ABI and STEM Supported ABI groups, the application named Mr. Y1ldiz was implemented. In this implementation, in order to prepare students for the argument process, the killer's identity is questioned through a mysterious death story, while the basic 
components of the argument are discussed in relation to what the concepts of claim, evidence, data and justification are and how they are formed. In addition, STEM Supported ABI group was informed about what STEM education is and how this education process will progress. The students were divided into groups of 4-5 people with their friends they chose and carried out the activities as a group throughout the application.

ABI group determined the research questions regarding the subjects specified in Table 1 and designed their experiments or conducted research to answer these questions. Based on the data they obtained as a result of their experiments and research, they formed their evidence and claims. Each group presented their claim along with their evidence in class discussion. During this process, the students listened to the presented arguments and discussed them. The groups supported each other if they had similar aspects in their own research, or continued the process by making a counter-argument if there was a situation contrary to their own research.

STEM Supported ABI group, on the other hand, determined the criteria and limitations specified in the problem first to solve the problems prepared for the subjects in Table 1. Then, each group identified a research question to solve the problem and made their designs to answer this question. Each group formed their claims, which included their design and answers to their questions, and supported them with evidence. The groups then presented their designs and each group evaluated their own and the other groups' designs in terms of criteria and limitations. The process followed during ABI and STEM Supported ABI applications are given in Table 1.

Table 1. ABI and STEM supported ABI application process

\begin{tabular}{|c|c|c|}
\hline The Stages & $\mathbf{A B I}$ & STEM Supported ABI \\
\hline 1 & $\begin{array}{l}\text { Preliminary tests applied } \\
\text { (Success test, Scientific creativity test } \\
\text { Reflective thinking scale) }\end{array}$ & $\begin{array}{l}\text { Preliminary tests applied } \\
\text { (Success test, Scientific creativity test } \\
\text { Reflective thinking scale) }\end{array}$ \\
\hline 2 & "Mr. Yildız" event was held & $\begin{array}{l}\text { "Mr. Y1ldiz" event was held and information } \\
\text { was given about STEM education. }\end{array}$ \\
\hline 3 & $\begin{array}{l}\text { The topic of "Mass and Weight" was handled } \\
\text { according to ABI approach. }\end{array}$ & $\begin{array}{l}\text { The subject of "Mass and Weight" was handled } \\
\text { according to the STEM-supported ABI } \\
\text { approach. } \\
\text { Dynamometer is designed. }\end{array}$ \\
\hline 4 & $\begin{array}{l}\text { The subject of "Force Work and Energy } \\
\text { Relationship" was handled according to ABI } \\
\text { approach. }\end{array}$ & $\begin{array}{l}\text { The subject of "Force Work and Energy } \\
\text { Relationship" was handled according to STEM } \\
\text { supported ABI approach. } \\
\text { Catapult is designed. }\end{array}$ \\
\hline 5 & $\begin{array}{l}\text { The subject of "Energy Conversions" was } \\
\text { handled according to ABI approach. }\end{array}$ & $\begin{array}{l}\text { The subject of "Energy Conversions" was } \\
\text { handled according to STEM supported ABI } \\
\text { approach. } \\
\text { Multi-purpose car is designed. }\end{array}$ \\
\hline 6 & $\begin{array}{l}\text { The subject of "Air and Water Resistance" was } \\
\text { handled according to ABI approach. }\end{array}$ & $\begin{array}{l}\text { The subject of "Air and Water Resistance" was } \\
\text { processed according to STEM supported ABI } \\
\text { approach. } \\
\text { Parachute is designed. }\end{array}$ \\
\hline 7 & $\begin{array}{l}\text { Final tests applied } \\
\text { (Success test, Scientific creativity test } \\
\text { Reflective thinking scale) }\end{array}$ & $\begin{array}{l}\text { Final tests applied } \\
\text { (Success test, Scientific creativity test } \\
\text { Reflective thinking scale) }\end{array}$ \\
\hline
\end{tabular}


During the application period, ABI Report was used in ABI group and STEM Report was used in STEM Supported ABI group. The ABI report consists of the following sections: "My question", "My initial thought", "What I do to answer my question (observation, experiment, research, etc.)", "What do I find, what are my claim, my evidence, and what do my classmates say?" "What I read, how does the information obtained from the source compare and contrast with my claims and evidence?" "My thoughts have changed/haven't changed because...". STEM supported ABI report consists of the following sections: "Determination of the problem situation", "Criteria and limitations of your problem", "My initial thought (What do we know? What do we need to know?)", "Determining the needs", "Developing solution suggestions", "Determining the best solution proposal (evaluate your proposal in terms of its limitations, what is your claim for your solution?)", "Making a model / design, testing and evaluating the solution", "Your design is successful in solving the problem and supporting your claim with evidence, and presenting a solution". These reports were written by the students individually in the classroom, simultaneously with the application process.

\section{Research ethics}

Before the research, the students were informed about it and it was stated that they could withdraw at any stage of the study. In addition, after the research, it was confirmed that the students did not suffer from any academic or mental issues. Due to scientific ethics, the name of the institution where the study was conducted and the names of the participants were not specified in the research.

\section{Data analysis}

SPSS 21 program was used to analyze the data. When the normality of the creativity pre-test and post-test scores was examined, the Shapiro-Wilk test analysis was performed because the sample number of both groups was small, and both groups' pre-test $(\mathrm{r}(\mathrm{ABI})=$ $.99, \mathrm{r}(\mathrm{ABI}+\mathrm{STEM})=.156$ and post-test scores $(\mathrm{r}(\mathrm{ABI})=.98, \mathrm{r}(\mathrm{ATBÖ}+\mathrm{ABI})=.31$ was determined to be normally distributed. Parametric analysis was preferred because the data were distributed normally. Independent Groups $\mathrm{T}$ Test was applied for the pre-post test findings of the scientific creativity test. Cronbach alpha reliability value for Scientific Creativity Test was determined as .80 .

When the distributions of the academic achievement pre-test and final test scores were examined, the Shapiro-Wilk test analysis was performed because the sample number of both groups was small. Pre-test of both groups $(\mathrm{r}(\mathrm{ABI})=.29, \mathrm{r}(\mathrm{ABI}+\mathrm{STEM})=.07)$ and the post-test scores $(\mathrm{r}(\mathrm{ABI})=.11, \mathrm{r}(\mathrm{ABI}+\mathrm{STEM})=.06)$ were determined to be normally distributed. Independent Groups $\mathrm{T}$ Test was applied for the pre-post test findings of the academic achievement test. Cronbach alpha reliability value of Academic Achievement Test was determined as .93.

When the normality of the Reflective Thinking pre-test and post-test scores was examined, the Shapiro-Wilk test analysis was performed because the sample number of both groups was small, and pre-test of both groups $(\mathrm{r}(\mathrm{ABI})=.97, \mathrm{r}(\mathrm{ABI}+\mathrm{STEM})=.17)$ and post-test scores $(\mathrm{r}(\mathrm{ABI})=.25, \mathrm{r}(\mathrm{ABI}+\mathrm{STEM})=.18)$ were determined to be normally distributed. Since there was a significant difference in the Reflective Thinking pre-tests between the two groups, ANCOVA analysis was performed for the post-test. Conditions required for ANCOVA 
analysis (it was determined that its variances were homogeneous and regressions were uniformly distributed) were fulfilled.

The Semi-Structured Interviews were analysed by using content analysis. Content analysis is a technique that allows researchers to indirectly examine human behaviour/thoughts (Fraenkel $\&$ Wallen, 2006). The researchers coded interview questions and analysed the data by creating categories and themes.

\section{Results}

\section{Findings regarding the scientific creativity test}

The results of the scientific creativity pre-test of ABI and ABI+ STEM group students are presented in Table 2 .

Table 2. Results of the Dependent Group T-Test for scientific creativity pre-test

\begin{tabular}{|c|c|c|c|c|c|c|c|}
\hline & Groups & $\mathbf{N}$ & $\overline{\boldsymbol{X}}$ & SE & $\mathbf{T}$ & df & $\mathrm{p}$ \\
\hline \multirow{2}{*}{ Fluency } & ABI & 21 & 15.00 & 9.21 & \multirow{2}{*}{1.974} & \multirow[t]{2}{*}{38} & \multirow{2}{*}{.056} \\
\hline & ABI+STEM & 20 & 20.55 & 8.55 & & & \\
\hline \multirow[b]{2}{*}{ Flexibility } & ABI & 21 & 10.05 & 6.03 & \multirow{2}{*}{.986} & \multirow{2}{*}{38} & \multirow{2}{*}{.331} \\
\hline & ABI +STEM & 20 & 11.70 & 4.43 & & & \\
\hline \multirow{3}{*}{ Originality } & $\mathrm{ABI}$ & 21 & 3.95 & 3.28 & \multirow[t]{2}{*}{1.249} & \multirow[t]{2}{*}{38} & \multirow[t]{2}{*}{.219} \\
\hline & ABI+STEM & 20 & 5.31 & 3.54 & & & \\
\hline & ABI & 21 & 29.00 & 16.92 & \multirow{3}{*}{1.591} & \multirow{3}{*}{38} & \multirow{3}{*}{.120} \\
\hline Scientific & & & & & & & \\
\hline $\begin{array}{l}\text { Creativity } \\
\text { Total }\end{array}$ & ABI +STEM & 20 & 37.01 & 14.51 & & & \\
\hline
\end{tabular}

When the results of the scientific creativity pre-test were examined, no statistically significant difference was found between the average of the total scores of the students in the ABI group

Table 3. Results of the Dependent Group T-Test for scientific creativity post-test

\begin{tabular}{|c|c|c|c|c|c|c|c|}
\hline & Groups & $\mathrm{N}$ & $\bar{X}$ & SE & $\mathrm{T}$ & $\mathrm{df}$ & $\mathrm{p}$ \\
\hline \multirow[t]{2}{*}{ Fluency } & $\mathrm{ABI}$ & 21 & 23.85 & 6.83 & \multirow[t]{2}{*}{-4.221} & \multirow[t]{2}{*}{38} & \multirow[t]{2}{*}{.000} \\
\hline & ABI +STEM & 20 & 33.90 & 8.16 & & & \\
\hline \multirow[t]{2}{*}{ Flexibility } & $\mathrm{ABI}$ & 21 & 13.90 & 4.44 & \multirow[t]{2}{*}{-3.935} & \multirow[t]{2}{*}{38} & \multirow[t]{2}{*}{.000} \\
\hline & ABI+STEM & 20 & 19.90 & 5.17 & & & \\
\hline \multirow{3}{*}{ Originality } & $\mathrm{ABI}$ & 21 & 4.35 & 2.21 & \multirow[t]{2}{*}{-2.642} & \multirow[t]{2}{*}{38} & \multirow[t]{2}{*}{.012} \\
\hline & ABI+STEM & 20 & 6.70 & 3.31 & & & \\
\hline & ABI & 21 & 42.10 & 11.78 & \multirow{3}{*}{-4.277} & \multirow{3}{*}{38} & \multirow{3}{*}{.000} \\
\hline Scientific & & & & & & & \\
\hline $\begin{array}{l}\text { Creativity } \\
\text { Total }\end{array}$ & ABI +STEM & 20 & 60.50 & 15.21 & & & \\
\hline
\end{tabular}


Similarly, when the sub-dimensions of the scientific creativity pre-test were examined, there was no significant difference between the two groups. The results of the scientific creativity post-test are presented in Table 3.

After the application, a significant increase was observed in the scientific creativity post-test total scores and the average of scientific creativity post-test sub-dimensions of both groups. However, according to the scientific creativity post-test results, the post-test total scores of $\mathrm{ABI}+$ STEM group $(\overline{\mathrm{X}}=60.50)$ and $\mathrm{ABI}$ group $(\overline{\mathrm{X}}=42.10)$ showed a statistically significant difference in favor of the ABI + STEM group [t $(38)=-4.277, p<.05, r=57]$. Similarly, in scientific creativity sub-dimensions, there is a significant difference between the two groups in favor of the ABI + STEM group. As a result, the scientific creativity scores of the group in which STEM supported ABI applications were carried out were significantly higher than the other group.

\section{Findings Regarding the Academic Achievement Test}

The results of the academic achievement test of ABI and ABI+ STEM group students are presented in Table 4.

Table 4. Results of the Dependent Group T-Test for academic achievement test pre and post test

\begin{tabular}{lllccccc}
\hline & Groups & $\mathbf{N}$ & $\overline{\boldsymbol{X}}$ & $\mathbf{S E}$ & $\boldsymbol{T}$ & $\mathbf{d f}$ & $\mathbf{p}$ \\
\hline \multirow{3}{*}{ Pre test } & ABI & 21 & 10.62 & 2.61 & & & \\
& ABI +STEM & 20 & 12.30 & 5.19 & -1.299 & 39 & .205 \\
\multirow{3}{*}{ Post test } & ABI & 21 & 14.24 & 5.07 & & & \\
\hline
\end{tabular}

When the results of the academic achievement test were examined, it was determined that there was no significant difference between the two groups for the academic achievement pretest results [t $(38)=-1.299, \mathrm{p}>05]$. When the post-test results were examined, the ABI + STEM group $(\overline{\mathrm{X}}=19.15)$ and ABI group $(\overline{\mathrm{X}}=14.24)$ showed a statistically significant difference $[\mathrm{t}(38)=-2.923, \mathrm{p}<.05, \mathrm{r}=.43]$. It was determined that the group teaching lessons with STEM supported ABI method was more successful.

\section{Findings from the reflective thinking scale for problem solving}

The pre-test results of the Reflective Thinking Scale for Problem Solving are given in Table 5.

Table 5. Results of the Dependent Group T-Test for the reflective thinking scale for problem solving pre test

\begin{tabular}{llllllll}
\hline & Groups & $\mathbf{N}$ & $\overline{\boldsymbol{X}}$ & $\mathbf{S S}$ & $\boldsymbol{T}$ & $\mathbf{d f}$ & $\mathbf{p}$ \\
\hline \multirow{4}{*}{ Inquiry } & & & & & & & \\
& ABI & 21 & 15.95 & 4.72 & -2.770 & 39 & .010 \\
\multirow{5}{*}{ Evaluation } & ABI+STEM & 20 & 19.05 & 1.93 & & & \\
& & & & & & & \\
& ABI & 21 & 17.33 & 3.70 & -2.750 & 39 & .009
\end{tabular}




\begin{tabular}{llllllll} 
& ABI & 21 & 13.33 & 3.56 & -3.098 & 39 & .004 \\
Reasoning & ABI+STEM & 20 & 16.40 & 2.68 & & & \\
& ABI & 21 & 46.62 & 11.23 & & 39 & .003 \\
Reflective & ABI +STEM & 20 & 55.55 & 5.90 & -3.207 & 39 \\
Thinking Total & & 21 & & & \\
\hline
\end{tabular}

When the pre-test scores of reflective thinking about problem solving were examined, the total test score between the two groups $[\mathrm{ABI} ; \overline{\mathrm{X}}=46.62$, SS $=11.23$ ABI + STEM; $\overline{\mathrm{X}}=$ $55.55, \mathrm{SS}=5.90 \mathrm{p}<05]$ showed significant difference. When the results of the subdimensions of the scale were examined, inquiry $[\mathrm{ABI} ; \overline{\mathrm{X}}=15.95, \mathrm{SS}=4.72, \mathrm{ABI}+\mathrm{STEM} ; \overline{\mathrm{X}}$ $=19.05, \mathrm{SD}=1.93 \mathrm{p}<05]$, evaluation $[\mathrm{ABI} ; \overline{\mathrm{X}}=17.33, \mathrm{SS}=3.70, \mathrm{ABI}+\mathrm{STEM} ; \overline{\mathrm{X}}=20.10$, $\mathrm{SD}=2.61 \mathrm{p}<05]$ and reasoning $[\mathrm{ABI} ; \overline{\mathrm{X}}=13.33, \mathrm{SS}=3.56, \mathrm{ABI}+\mathrm{STEM} ; \overline{\mathrm{X}}=16.40, \mathrm{SS}=$ $2.68 \mathrm{p}<05]$ showed a significant difference.

Since there was a significant difference in pre-test scores between the two groups, ANCOVA analysis was applied for the post-test. The post-test results of the Reflective Thinking Scale for Problem Solving are given in Table 6.

Table 6. Results of the ANCOVA for the reflective thinking scale for problem solving post test

\begin{tabular}{|c|c|c|c|c|c|c|}
\hline & Source & $\begin{array}{l}\text { Sum of } \\
\text { Squares }\end{array}$ & df & $\begin{array}{l}\text { Mean } \\
\text { Square }\end{array}$ & $\mathbf{F}$ & $\mathbf{p}$ \\
\hline \multirow[t]{4}{*}{ Inquiry } & Pre test & 94.849 & 1 & 94.849 & 6.725 & .013 \\
\hline & Group & 211.930 & 1 & 211.930 & 15.025 & .000 \\
\hline & Error & 535.987 & 34 & 14.105 & & \\
\hline & Total & 14780.00 & 41 & & & \\
\hline \multirow{4}{*}{ Evaluation } & Pre test & 14.939 & 1 & 14.939 & .784 & .382 \\
\hline & Group & 194.048 & 1 & 194.048 & 10.178 & .003 \\
\hline & Error & 724.499 & 38 & 19.066 & & \\
\hline & Total & 15010.00 & 41 & & & \\
\hline \multirow[t]{4}{*}{ Reasoning } & Pre test & 15.488 & 1 & 15.488 & 1.059 & .310 \\
\hline & Group & 64.802 & 1 & 64.802 & 4.429 & .042 \\
\hline & Error & 556.014 & 38 & & & \\
\hline & Total & 9876.000 & 41 & & & \\
\hline Reflective & Pre test & 375.470 & 1 & 5763.321 & 3.210 & .081 \\
\hline Thinking & Group & 1404.045 & 1 & 1404.045 & 12.005 & .001 \\
\hline \multirow[t]{2}{*}{ Total } & Error & 4358.451 & 37 & 117.796 & & \\
\hline & Total & 116928.000 & 41 & & & \\
\hline
\end{tabular}

When Table 6 was examined, it was found that there was a statistically significant difference between the two groups in favor of the group using the STEM-supported ABI method for Reflective Thinking scores of students for Post-Test problem solving $[\mathrm{F}(1,38)=12.005, \mathrm{p}$ $<.05]$. For all sub-dimensions of the Reflective Thinking Scale for Problem Solving (inquiry $[\mathrm{F}(1,38)=15.025, \mathrm{p}<.05]$, evaluation $[\mathrm{F}(1,38)=10.178, \mathrm{p}<.05]$ and reasoning $[\mathrm{F}(1), 38)=$ $4.429, \mathrm{p}<.05])$ there was a statistically significant difference in favor of the STEM Supported ABI group. Therefore, STEM supported ABI application has increased students' reflective thinking about problem solving more. 


\section{Findings obtained from students' opinions on ABI and STEM supported ABI activities}

When the results of the semi-structured interviews with the students at the end of the application process were examined, 3 themes were determined. These are the positive and negative aspects of the teaching process (ABI and ABI + STEM) and the students' developing skills in the process. Both groups stated that the activities that take place during the teaching process allow them to learn the subject, increase their academic success, have a fun learning environment, and the process helps them gain positive thoughts (self-confidence, motivation, happiness, thinking like a scientist). Unlike the other group, students in the STEM-supported ABI group stated that this process supports them to create new ideas. Student views are presented in Table 7.

Another theme obtained in student interviews is the difficulties experienced in the process. Students in both groups stated that some of their friends, especially in group work, did not fulfill their duties and responsibilities. Another theme is the developing skills of the students in the process. Students in both groups stated that their creativity and experimentation skills improved. In addition, the ability to design is among the developing skills. The ABI group stated that their skills in designing experiments developed more, while the ABI + STEM group got the tool-design skill improved besides designing an experiment. He expressed that his design skills improved. Also, ABI + STEM group drew attention to the development of psychomotor skills. See Table 7 (continued). 
Table 7. Students' views on ABI and STEM supported ABI activities

\begin{tabular}{|c|c|c|c|c|}
\hline Group & Theme & Code & Example of Student Expressions & \\
\hline \multirow[t]{6}{*}{ ABI } & \multirow[t]{6}{*}{$\begin{array}{l}\text { Positive } \\
\text { sides }\end{array}$} & $\begin{array}{l}\text { Subject } \\
\text { Learning }\end{array}$ & $\begin{array}{l}\text { "Yes, they did. I can understand the subject better. " "I understood the lesson and the subject more clearly." } \\
\text { "It helped me to understand and comprehend the subjects well" "I understand better and learn faster and easier with the } \\
\text { activities" "We experience and apply and learn because we do the activities ourselves" "I discovered and learned new } \\
\text { things" }\end{array}$ & 8 \\
\hline & & Academic success & "I felt successful in science lesson" "I found myself successful in my science lesson" & 4 \\
\hline & & $\begin{array}{l}\text { Learning by having } \\
\text { fun }\end{array}$ & $\begin{array}{l}\text { "We both had fun and learned the subject" "It became more fun with the activities, it made the subject fun""It made me } \\
\text { learn in a more fun way" "The lesson was more enjoyable and fun/satisfactory/delightful" }\end{array}$ & 6 \\
\hline & & $\begin{array}{l}\text { Positive thinking } \\
\text { (happiness, }\end{array}$ & $\begin{array}{l}\text { "I was happy during the lesson", "It felt good" "I felt like a scientist", } \\
\text { "I increased my motivation for the lesson "'" I was proud of myself " }\end{array}$ & \\
\hline & & $\begin{array}{l}\text { motivation, self- } \\
\text { confidence, etc.) }\end{array}$ & "I felt successful because what I learned remained in my mind" & 8 \\
\hline & & Research inquiry & "My thinking speed became more efficient because I was always in a state of thinking" & 1 \\
\hline \multirow{5}{*}{$\begin{array}{l}\text { ABI } \\
+ \\
\text { STEM }\end{array}$} & \multirow[t]{5}{*}{$\begin{array}{l}\text { Positive } \\
\text { sides }\end{array}$} & $\begin{array}{l}\text { Subject } \\
\text { Learning }\end{array}$ & $\begin{array}{l}\text { "I learned a lot about science" "I understood many subjects better." "We did educational activities." "We reinforced the } \\
\text { subject with the designs we made" "We did educational activities. "We learned new things as a result of the design." }\end{array}$ & 17 \\
\hline & & $\begin{array}{l}\text { Learning by having } \\
\text { fun }\end{array}$ & $\begin{array}{l}\text { "Doing these activities made me feel happy." "We have the lesson in a fun way with activities." } \\
\text { "STEM activities provided us with both a fun atmosphere and information." "We're having a good time." }\end{array}$ & 5 \\
\hline & & $\begin{array}{l}\text { Positive thinking } \\
\text { (happiness, } \\
\text { motivation, } \\
\text { self-confidence etc.) }\end{array}$ & $\begin{array}{l}\text { "Doing these activities increased my confidence." "It made me discover my talents" } \\
\text { "We thought about the things we couldn't do and found these even if it was difficult. " "Designing made me feel good } \\
\text { since we did drawing and thinking work." "I felt like an inventor." } \\
\text { "I think I will do better because I improve myself." }\end{array}$ & 9 \\
\hline & & Research inquiry & $\begin{array}{l}\text { "Now, thanks to these activities, I think and try to implement the best solution." } \\
\text { "There are a lot of questions to investigate, and while I am investigating these questions, I am confronted with things I do } \\
\text { not know and I want to investigate those questions." }\end{array}$ & 3 \\
\hline & & Generating ideas & "I thought of new ideas for reusing things." "I can think of many ideas." & 7 \\
\hline
\end{tabular}


Table 7. Students' views on ABI and STEM supported ABI activities (Continued).

\begin{tabular}{|c|c|c|c|c|}
\hline Group & Theme & Code & Students' idea & $\mathbf{f}$ \\
\hline ABI & $\begin{array}{l}\text { Experienced } \\
\text { troubles }\end{array}$ & $\begin{array}{l}\text { Distribution of tasks } \\
\text { within the group }\end{array}$ & $\begin{array}{l}\text { "On the negative side, my group friends } \\
\text { constantly bothered me while the lesson was } \\
\text { being taught." }\end{array}$ & 2 \\
\hline $\begin{array}{l}\text { ABI } \\
+ \\
\text { STEM }\end{array}$ & $\begin{array}{l}\text { Experienced } \\
\text { troubles }\end{array}$ & $\begin{array}{l}\text { Distribution of tasks } \\
\text { within the group }\end{array}$ & $\begin{array}{l}\text { "Some of my friends in the group did not } \\
\text { fulfill their responsibilities." } \\
\text { "I did most of the things myself in group } \\
\text { work." } \\
\text { "I got angry when my friends didn't do } \\
\text { anything" }\end{array}$ & 4 \\
\hline \multirow[t]{3}{*}{$\mathrm{ABI}$} & Skills Acquired & Creativity & $\begin{array}{l}\text { "It affected my creativity because I } \\
\text { discovered new things", "It improved my } \\
\text { creativity", "My creativity increased as I did } \\
\text { experiments", "The activities I did increased } \\
\text { my creativity" }\end{array}$ & 12 \\
\hline & & $\begin{array}{l}\text { Experiment and } \\
\text { observation }\end{array}$ & $\begin{array}{l}\text { "We understand better by doing } \\
\text { experiments" } \\
\text { "It increased my ability to experiment" } \\
\text { "We observe more" }\end{array}$ & 7 \\
\hline & & Design & $\begin{array}{l}\text { "We created designs, I learned more with } \\
\text { them", "We designed experiments", "I } \\
\text { designed something in my mind related to the } \\
\text { subject and applied it", }\end{array}$ & 3 \\
\hline \multirow[t]{4}{*}{$\begin{array}{l}\text { ABI } \\
+ \\
\text { STEM }\end{array}$} & Skills Acquired & Creativity & $\begin{array}{l}\text { "I think it affects my creativity because now } \\
\text { we are accomplishing better and harder } \\
\text { things than before." } \\
\text { "We are constantly thinking about what kind } \\
\text { of a new invention we will make. Thus, our } \\
\text { creativity improves" } \\
\text { "My creativity has improved because I have } \\
\text { developed new ideas" }\end{array}$ & 15 \\
\hline & & Design & $\begin{array}{l}\text { "Now I have started to design something on } \\
\text { my own.", } \\
\text { "We designed in science class." }\end{array}$ & 6 \\
\hline & & Experimentation & $\begin{array}{l}\text { "I've learned to do experiment." } \\
\text { "My experiment skill improved" }\end{array}$ & 5 \\
\hline & & Psychomotor skill & $\begin{array}{l}\text { "Our hand and arm coordination and hand } \\
\text { skills improved." }\end{array}$ & 3 \\
\hline
\end{tabular}

\section{Conclusion and Discussion}

The focus of the research is to investigate the effects of ABI and STEM supported ABI applications on students' scientific creativity, reflective thinking skills for problem solving and academic success. In this context, if we consider the research results one by one, it was determined that the scientific creativity of both groups increased at the end of the study, but the scientific creativity scores of the group in which STEM supported ABI applications were carried out were significantly higher than the other group. There are studies suggesting that ABI method positively affects students 'creative thinking (Küçük Demir, 2014; Özcan, 2019) and similarly STEM 
education increases students' creative thinking skills (Gülhan, 2016; Hacığlu, 2017). However, studies indicating that STEM education has a moderate effect on students' creative thinking are also included in the literature (Ceylan, 2014; Mayasari, Kadarohman, Rusdiana, \& Kaniawati, 2016). With this study, it can be said that the combination of STEM approach and ABI approach affected the development of students' scientific creativity more compared to the ABI approach used alone. That is, using two methods together positively affects scientific creativity (Gökbayrak \& Mixan, 2017)

In the research, it was concluded that students' reflective thinking skills for problem solving are more developed in applications made by integrating STEM into the ABI approach. This supports the result that the STEM approach is effective in obtaining $21^{\text {st }}$ century skills and among them the reflective thinking skill (Akgündüz, 2015; Çorlu, 2014; Daugherty, 2012; Dejarnette, 2012). The development of students' reflective thinking in solving problems can be explained in the following way: ABI approach provides students with the opportunity to identify the problem / research question related to the subject and seek answers (experiment, observe and research), write their changing / unchanged thoughts in the ABI reports with their reasons, question their own thoughts, evidences, claims and allegations of their friends, and work collaboratively. The STEM approach, on the other hand, provides students with the problem and solution process and gives the opportunity to design (think, design, question / change / evaluate the design) in line with the solution of the problem. In this way, students' reflective thinking skills towards problem solving are expected to develop. Because the development of reflective thinking is based on the student's experiences, skills and cognitive structure (Sharon, 2007). During STEM-integrated ABI activities, students choose appropriate strategies to explore the problem they encounter and structure the information necessary to solve the problem (Gülen, 2016). Therefore, it is possible to say that STEM supported argumentation practices offer opportunities for actions that demonstrate reflective thinking skills such as questioning, evaluating, and reasoning. In addition, the moderate relationship between students' reflective thinking levels and problem-solving abilities, and their conversations with each other in a group affect their reflective thinking (Demirel, Derman, \& Karagedik, 2015).

Another focus of the research can be about the following, the results in terms of academic success were examined and it was concluded that the group in which STEM integrated $\mathrm{ABI}$ applications were performed was more successful compared to the ABI group. The reason for this situation can be explained by the fact that using more than one approach while teaching the lesson makes the lesson more effective and these two support each other. Similarly, Gülen (2016) stated that the STEM-integrated ABI approach has a positive effect on students' academic achievements and reflective thinking skills. In Külekçi's (2019) study, students have implemented problem-based STEM applications supported by concept caricature, and it has been concluded that students' academic success has increased. Findings obtained from student interviews of this research support this result. Especially, most of the students $(f=17)$ in the group in which STEM supported ABI applications were carried out stated that this process enabled them to learn the subject. In the literature, besides many studies showing that the ABI method increases the academic success of students, it is also striking that the traditional methods also have a similar effect (Demirel, 2015). The result that STEM education also increases academic achievement is emphasized in many studies in the literature (Acar, Tertemiz \& Taşdemir, 2018; Ceylan, 2014; Ercan, 2014; Fortus, et. al., 
2004; 2005; Y1ldırım \& Altun, 2015). For example, Nağaç (2018) carried out STEM applications with 6th grade students on problems that can be encountered directly in daily life such as "Thermal Insulation of Buildings" and "Stove and Natural Gas Poisoning" and found that STEM applications enable students to learn permanently.

Inquiry-based STEM activities increase children's motivation for science, change their perception towards science positively, and improve their scientific process skills and engineering skills (Dilek, Tasdemir, Konca, \& Baltaci, 2020). When the discourses of the students in the study were examined, it was found that this process increased students' motivation and self-confidence and made the lesson more fun. In addition to these, it is noted that this method supports producing new ideas in the STEM-supported ABI group. However, it is emphasized that in the STEM supported ABI group, students' skills such as creativity, experimenting, and designing improved more. Because while designing or creativity in the ABI approach is limited to the process of designing an experiment, the STEM approach provides students with a tool, machine, method, and others that offer the opportunity to design. Thus, it strengthens the effect of ABI activities. Similarly, the ABI procedure also offers the opportunity to argue that the product designed by students is the best solution proposal thanks to its inherent ability to convince the opposite side by creating claims, evidence, rebuttals and counterarguments. At the same time, it can support entrepreneurial characteristics by owning the product made. Özcan and Balım (2021) noted that socio-scientific argumentation positively affected the students' entrepreneurship perception, innovation perception, tendency creativity and leadership.

As a result, it is possible to say that both ABI and STEM approaches positively affect students' academic achievement, scientific creativity and reflective thinking towards problem solving, but the integration of the two approaches will produce more positive results. The integration of STEM (Stohlmann, Moore \& Roehrig, 2012), an educational approach formed by the integration of disciplines, with ABI, an inquiry approach, enriches the learning environment and diversifies the results. At the same time, the two learning approaches can strengthen each other's weaknesses. In future studies, research can be conducted on how the STEM approach can be integrated with different methods and approaches, the positive and negative sides of this, and how it will affect students and teachers. In this way, new opportunities can be created for us to understand, learn and apply the STEM approach, which is a relatively novel method for educators.

\section{References}

Acar, D., Tertemiz, N., \& Taşdemir, A. (2018). The Effects of STEM Training on the Academic Achievement of 4th Graders in Science and Mathematics and their Views on STEM Training. International Electronic Journal of Elementary Education, 10(4), 505-513.

Akgündüz, D. (2015). STEM eğitimi çalıştay raporu Türkiye STEM eğitimi üzerine kapsamlı bir değerlendirme [STEM education workshops a comprehensive assessment report on Turkey STEM education]. İstanbul Aydin University.

Aktaş, T. (2017). The effect of argument driven inquiry method in teaching of 'force and energy' unit on the academic achievements of seventh grade students and their argumentation levels (Unpublished master thesis). Marmara University: İstanbul. 
Aranda, M. L., Lie, R., \& Guzey, S. S. (2020). Productive thinking in middle school science students' design conversations in a design-based engineering challenge, International Journal of Technology and Design Education, 30(1), 67-81.

Aydın, G., Saka, M., \& Guzey, S. (2017 ). Science, Technology, Engineering, Mathematic (STEM) Attitude Levels In Grades 4th - 8 th, Mersin University Journal of the Faculty of Education, 13(2), 787-802.

Aydın, Ö. \& Kaptan, F. (2014). Effect of argumentation on metacognition and logical thinking abilities in science-technology teacher candidate education and opinions about argumentation, Journal of Educational Sciences Research, 4(2), 163-188.

Aydoğdu, Z. (2017). Investigation of effects the argumentation based science teaching on the academic success, motivation, interest and attitudes towards science (Unpublished master thesis). Sakarya University:, Sakarya.

Aygen, M.B. (2018). Stem applications for supporting integrated teacher knowledge of science teacher candidates (Unpublished master thesis). Frrat University: Elazığ.

Başar, S. (2018). Self-efficacy beliefs in the use of mathematics in science of the candidate science teachers, 21. century skills and the relationship between these (Unpublished master thesis). Hacettepe University: Ankara.

Baydas, O., Yesildag-Hasancebi, F., \& Kilis, S. (2018). An investigation of university students' discussion process in argumentation based inquiry approach, Inonu University Journal of the Faculty of Education, 19(3), 564-581. DOI: 10.17679/inuefd.341522

Berland, L. K. \& Reiser, B. J. (2011). Classroom communities' adaptations of the practice of scientific argumentation, Science Education, 95(2), 191-216.

Bodner, G. \& Elmas, R. (2020). The Impact of Inquiry-Based, Group-Work Approaches to Instruction on Both Students and Their Peer Leaders, European Journal of Science and Mathematics Education, 8(1), 51-66.

Cavagnetto, A., Hand, B. M., \& NortonMeier, L. (2010). The nature of elementary student science discourse in the context of the science writing heuristic approach, International Journal of Science Education, 32(4), 427-449.

Cengiz, C., \& Kabapınar, F. (2017). Effect of Implicit Argumentation education on PSTs' understandings about NOS, Journal of the Turkish Chemical Society Chemical Education, 2(1), 19-62.

Ceylan, S. (2014). A study for preparing an instructional design based on science, technology, engineering and mathematics (STEM) approach on the topic of acids and bases at secondary school science course. (Unpublished master thesis). Uludağ University: Bursa.

Clark, V. L. P., \& Creswell, J. W. (2014). Understanding research: A consumer's guide. Pearson Higher Ed.

Çınar, D. (2013). The effect of argumentation based science instruction on 5th grade students' learning outcomes (Unpublished doctoral thesis), Necmettin Erbakan University, Konya.

Çorlu, M. S. (2014). Call for manuscripts on STEM education. Turkish Journal of Education, 3(1), 4-10.

Daugherty, J. (2012). Infusing engineering concepts: Teaching engineering design. National Center for Engineering and Technology Education. http://files.eric.ed.gov/fulltext/ED537384.pdf (Erişim tarihi: 2019, 6 Aralık).

Dejarnette, N. K. (2012). America's Children: Providing Early Exposure to STEM (Science, Technology, Engineering and Math) Initiatives, Reading Improvement, 
131 (4), 180- 181. http://search.ebscohost.com/login.aspx?direct=true\&db= edsgao\&AN=edsgcl.476727925\&lang=tr\&site=eds-live\&authtype=ip,uid (Erişim tarihi: 2018, 15 Kasım).

Demirel, M., Derman, I., \& Karagedik, E. (2015). A study on the relationship between reflective thinking skills towards problem solving and attitudes towards mathematics, Procedia - Social and Behavioral Sciences, 197, 2086 - 2096.

Demirel, R. (2015). The effect of individual and group argumentation on student academic achievement in force and movement issues, Journal of Theory \& Practice in Education, 11(3), 916-948.

Demirel, T. (2017). The effect of augmented reality activities supported by argumentation approach on academic achievement, critical thinking skills, motivation towards science and technology course and argumentation skills. (Unpublished doctoral thesis), Çukurova University: Adana.

Deniş, H., \& Balım, A. G. (2012). Adaptation of scientific creativity test to turkish and it's assessment criterias, Uşak University Journal of Sociol Science, 5(2), 1-21.

Dilci, T., \& Babacan, T. (2012). The views of the primary school teachers' depending on the fifth grade curriculum in development of reflectıve thınking skills, Sivas Cumhuriyet University Faculty of Letters Journal of Social Sciences, 36(1), 141161.

Dilek, H., Tasdemir, A., Konca, A.S., \& Baltaci, S. (2020). Preschool children's science motivation and process skills during inquiry-based STEM activities, Journal of Education in Science, Environment and Health (JESEH), 6(2), 92-104.

Driver, R., Newton, P., \& Osborne, J. (2000). Establishing the norms of scientific argumentation in classrooms, Science Education, 84(3), 287-312.

Dugger, W. E. (2010). Evolution of STEM in the United States. In 6th Biennial international conference on technology education research, Gold Coast, Queensland, Australia.

Duru, M., Demir, S., Önen, F., \& Benzer, E. (2011). the effects of inquiry-based laboratory applications to preservice science teachers' laboratory environment perceptions, attitudes and scientific process skills, Marmara University Atatürk Education Faculty Journal of Educational Sciences, 44(33), 25-44

Ecevit, T., \& Kaptan, F. (2019). Describing the argument based 1nquiry teaching model designed for gaining the 21 st century skills. Hacettepe University Journal of Education. Advance online publication. doi: 10.16986/HUJE.2019056328

Elmas, R., \& Gül, M. (2020). Examination of the applicability of stem education approach in the context of 2018 science curriculum, Journal of Turkish Chemical Society Section C: Chemistry Education, 5(1), 224-247

Ercan, S. (2014). The usage of engineering practices in science education: Design based science learning. (Unpublished doctoral thesis), Marmara University: İstanbul.

Erdoğan, S. (2010). Investigate the effects of teaching earth, sun and moon topics through argumentation on the success, attitude and argumentation skills of 5th grade students. (Unpublished master thesis). Uşak University, Uşak.

Erenler, S. (2017). The effect of argument driven inquiry (adi) method on pre-service science teachers' metacognitive awareness and scientific writing skills. . (Unpublished master thesis). Abant İzzet Baysal University: Bolu.

Eroğlu, S., \& Bektaş, O. (2016). Ideas of science teachers took stem education about stem based activities, Journal of Qualitative Research in Education, 4(3), 43-67. 
Ertek, Y., Ertek, E., \& Güneş, B. (2013) Investigation of the relationship between scientific process skills and problem solving skills included in the physics curriculum, Science Education and Research Association Journal of Science Education 1(2), 110- 121.

Fortus, D., Dershimer, R. C., Krajcik, J., Marx, R. W., \& Mamlok-Naaman, R. (2004). Design-based science and student learning, Journal of Research in Science Teaching, 41(10), 1081-1110.

Fortus, D., Krajcik, J., Dershimer, R. C., Marx, R. W., \& Mamlok-Naaman, R. (2005). Design-based science and real-world problem-solving, International Journal of Science Education, 27(7), 855-879.

Gazibeyoğlu, T. (2018). Investigation of the effect of stem applications on achievement in force and energy unit and attitudes towards science course of 7th grade students. (Unpublished master thesis). Kastamonu University, Kastamonu.

Gökbayrak, S., \& Karışan, D. (2017). An investigation of the effects of STEM based activities on preservice science teacher's science process skills, Western Anatolia Journal of Educational Sciences, 8(2), 63-84.

Gülen, S., \& Yaman, S. (2018). The opinions of sixth grade students about absl approach activities based on STEM, International Journal of Society Researches, 8(15), 1293-1322.

Gülen, S. (2016). The effect of argument driven inquiry (adi) method on pre-service science teachers' metacognitive awareness and scientific writing skills. (Unpublished master thesis). Ondokuz Mayis University, Samsun.

Gülhan, F. (2016). The effects of the integration of science-technology engineeringmathematics (STEM) on 5th grade students' perception, attitude, conceptual understanding and scientific creativity. (Unpublished doctoral thesis), Marmara University:İstanbul.

Gülseven, E. (2020). The effect of argumentation based stem education on 7th grade students academic achievements, attitude, and argumentation levels on unit of the force and energy. (Unpublished master thesis). Van Yüzüncü Y1l University, Van.

Gündüz, S., \& Odabaş1, F. (2004). The importance of instructional technologies and material development course at pre-service teacher education in information age, The Turkish Online Journal of Educational Technology, 3(1), 43-48.

Güvenç, Z. (2012). The relationship between the reflective thinking skills and emotional intelligences of class teachers. (Unpublished doctoral thesis), Pamukkale University: Denizli.

Hacioğlu, Y. (2017). The effect of science, technology, engineering and mathematics (STEM) education based activities on prospective science teachers' critical and creative thinking skills. (Unpublished doctoral thesis), Gazi University:Ankara.

Hand, B., \& Keys, C. W. (1999). Inquiry investigation, The Science Teacher, 66(4), 27.

Hiğde, E., \& Aktamış, H. (2017). Fen bilgisi öğretmen adaylarının argümantasyon temelli fen derslerinin incelenmesi: Eylem araştırması [Examination of argumentation-based science lessons of pre-service science teachers: Action research,], Elementary Education Online, 16(1), 89-113.X

Hu, W., \& Adey, P. (2002). A scientific creativity test for secondary school students, International Journal of Science Education, 24(4), 389-403.

İsikar, Y. (2017). The effect of the argumentation based teaching method on students' academic success, scientific process skills and attitude within the context of the chapter: Let's get to know substance (Unpublished master thesis), FiratUniversity: Elazığ. 
İşleyen, T., \& Küçük, B. (2013). Examining prospective teachers' level of creative thinking in terms of different variables, Mustafa Kemal University Journal of Social Sciences Institute ,10(21), 199-208.

İşman, A., \& Gürgün, S. (2008). Özel okullarda öğrenim gören ilköğretim öğrencilerinin internete yönelik tutum ve düşünceleri (Acarkent doğa koleji örneği) [Attitudes and thoughts of primary school students studying in private schools towards the internet (example of acarkent nature college)]. Presented orally at the 8th International Educational Technology Conference (IETC). Anadolu University, Eskişehir.

Kadayıfç1, H. (2008). The effect of an instructional model based on creative thinking on students' conceptual understanding of separation of matter subject and their scientific creativity. (Unpublished doctoral thesis), Gazi University: Ankara.

Karakuş, Y., \& Yalçın, O. (2016). The effect of the argümantation-based learning in science education to the academic achievement and scientific process skills: A Meta analysis study. Anadolu University Journal of Social Sciences, 16(4), 1-20. Doi: $10.18037 /$ ausbd.415534

Kardaş, N. (2013). The impact of argumentation focused teaching in science education on the decision making and problem solving skills of students. (Unpublished master thesis), Eskişehir Osmangazi University: Eskişehir.

Kaya, M. (2018). Student learning science-based approach argumentation of success and the effect of attitude. (Unpublished master thesis), Firat University: Elaziğ.

Kizılkaya, G., \& Askar, P. (2009). The Development of A Reflective Thinking Skill Scale towards Problem Solving, Education and Science, 34(154), 82-93.

Kibar, H. (2019). Analyzing effects of the argument-based inquiry approach on teaching the subject of heredity and bio-diversity to 10th grade students. (Unpublished master thesis), Marmara University: İstanbul.

Korkmaz, Ö., Çakır, R., \& Uğur Erdoğmuş, F. (2021). Secondary school students' basic STEM skill levels according to their self-perceptions: A scale adaptation. Participatory Educational Research, 8(1), 423-437.

Kutluer, M. (2020). The effect of argumentation based science learning approaches on 8th grade students' success at the subjects of cycles of matter and environmental problems and on their argumentation levels. (Unpublished master thesis), GaziUniversity, Ankara.

Kuvaç, M. (2018). The effectiveness of instructional design on science, technology, engineering and mathematics (STEM) based environmental education. (Unpublished doctoral thesis), İstanbul University: İstanbul.

Küçük Demir, B. (2014). The effect of the argumentation based science learning approach on students' mathematical achievement and skills of creative thinking (Unpublished doctoral thesis), Atatürk University, Erzurum.

Külekci, E. (2019). Effects of concept cartoon assisted problem based science, technology, engineering and mathematics (stem) activities on 5th grade science teaching (Unpublished master thesis), Manisa Celal BayarUniersity, Manisa.

Leech, N. L. \& Onwuegbuzie, A. J. (2007). A typology of mixed methods research designs, Qual Quant of Education, 43(1), 265-275.

Leou, M., Abder, P., Riordan, M., \& Zoller, U. (2006). 'Using HOCS-centered learning' as a pathway to promote science teachers' metacognitive development, Research in Science Education, 36(1-2), 69-84.

Margot, K. C., \& Kettler, T. (2019). Teachers' perception of STEM integration and education: a systematic literature review, International Journal of STEM Education, 6(1), 2. 
Mayasari, T., Kadarohman, A., Rusdiana, D., \& Kaniawati, I. (2016). Apakah model pembelajaran problem based learning dan project based learning mampu melatihkan keterampilan abad 21, Jurnal Pendidikan Fisika Dan Keilmuan (JPFK), 2(1), 48-55.

MoNE (Ministry of National Education, Turkey) (2013). Illkögretim kurumları fen bilimleri dersi öğretim programı [Primary education institutions' science instruction program]. Ankara, Turkey: Talim Terbiye Kurulu BaşkanlığI [Regulation of Board of Education]..

MoNE (Ministry of National Education, Turkey) (2018). Fen bilimleri dersi ögretim programı [Science curriculum]. Ankara, Turkey: Talim Terbiye Kurulu BaşkanlığI [Regulation of Board of Education].

Moore, T. J., \& Smith, K. A. (2014). Advancing the state of the art of STEM integration, Journal of STEM, Innovations and Research Education, 15(1), 5-10.

Moore, T. J., Guzey, S. S., \& Brown, A. (2014). Greenhouse design to increase habitable land: An engineering unit, Science Scope, 37(7), 51-57.

NAE \& NRC (2009). Engineering in K-12 education understanding the status and improving the prospects (L. Katehi, G. Pearson \& M. Feder, Eds.). Washington DC: National Academies.

Nağaç, M. (2018). An analysis of the effects of science, technology, engineering and mathematics (STEM) education method on the academic success and problem solving skills of 6th grade students for matter and heat unit in science course. (Unpublished master thesis), Hatay Mustafa Kemal University: Hatay.

Namdar, B., \& Salih, E. (2017). Preservice science teachers' views of technologysupported argumentation, Abant Izzet Baysal University Journal ofFaculty of Education, 17(3), 1384-1410.

National Research Council [NRC] (2011). Successful K-12 STEM education: Identifying effective approaches in science, technology, engineering, and mathematics, National Academies Press.

National Science Board [NSB] (2007). National Action Plan for Addressing the Critical Needs of U.S. Science, Technology, Engineering, and Mathematics Education System, Retrieved from.https://www.nsf.gov/pubs/2007/nsb07114/nsb07114.pdf

Orhon, G. (2011). Yaratıcılı; Nörofizyolojik, felsefi ve eğitsel temeller [Creativity; Neurophysiological, philosophical and educational foundations], Pegem Akademi, Ankara.

Orpwood, G., Schmidt, B., \& Jun, H. (2012). Competing in the 21st century skills race. Ottawa, ON, Canada: Canadian Council of Chief Executives.

Osborne, J., Simon, S., \& Collins, S. (2003) Attitudes towards science: A review of the literature and its implications, International Journal of Science Education, 25(9), 1049-1079.

Özcan, E. (2019). Investigation of the effect of argumentation based science learning approach on students conceptual understandings, creative thought and epistemological beliefs. (Unpublished master thesis), Marmara University: İstanbul.

Özcan, E., \& Balım, A. (2021).The effect of socio-scientific Argumantation Method on students' entrepreneurships. Participatory Educational Research, 8(1), 309-321.

Özdem, Y., Ertepinar, H., Çakiroglu, J., \& Erduran, S. (2013) The nature of pre-service science teachers' argumentation in inquiry-oriented laboratory context, International Journal of Science Education, 35(15), 2559- 2586. 
Öztürk, Z.D. (2019). The effect of problem based learning method on students' academic achievements and scientific process skills in a science course. (Unpublished master thesis), Pamukkale University, Denizli.

Radloff, J., \& Guzey, S. (2016). Investigating preservice STEM teacher conceptions of STEM education, Journal of Science Education and Technology, 25(5), 759774.

Roberts, R. J. (2012). Fish pathology. John Wiley \& Sons.

Robinson, S. K. (2003). Yaratıcılık-Aklın sinırlarını aşmak [Creativity-Transcending the limits of the mind] (N. G. Koldaş Çev.). İstanbul: Kitap.

Scott, J. W. (2009). The politics of the veil. Princeton University Press.

Senemoğlu, N. (1996). Yaratıcılık ve öğretmen nitelikleri [Creativity and teacher qualifications.]. Yaratıcılık ve Eğitim Paneli[Creativity and Education Panel]. Ankara: Kara Harp Okulu [Turkish Military Academy], 1, 2016.

Sharon, D. (2007). Simulation as an educational strategy in the development of critical and reflective thinking: A qualitative exploration (unpublished doctor of philosophy). Texas Woman's University, Texas.

Stohlmann, M., Moore, T. J., \& Roehrig, G. H. (2012). Considerations for teaching integrated STEM education, Journal of Pre-College Engineering Education Research (J-PEER), 2(1), 4.

Şahin, A., Ayar, M. C., \& Adiguzel, T. (2014). STEM related after-school program activities and associated outcomes on student learning, Educational Sciences: Theory and Practice, 14(1), 309-322.

Şen, Ş., Y1lmaz, A., \& Erdoğan, Ü. I. (2016). Prospective teachers' views of inquirybased laboratory activities, Elementary Education Online, 15(2), 443-468.

Şensoy, Ö., \& Aydoğdu, M. (2008). The effect of inquiry-based science instruction approach on the development of self-efficacy belief levels intended for science teaching of secondary science education teacher candidates, Gazi University Journal of Gazi Educational Faculty, 28(2), 69-93.

Tekelli, A. (2009). The effect of an argumentation-centered class environment on the conceptual change about acid-base and the understanding nature of science. (Unpublished master thesis), Gazi University: Ankara.

Tezci, E., \& Gürol, A. (2002). Oluşturmacı öğretim tasarımında teknolojinin rolü [The role of technology in constructivist instructional design.]. I. Uluslararası Eğitim Teknolojileri Sempozyumu'nda sunulmuş bildiri [Paper presented at the I. International Educational Technologies Symposium.]. Sakarya University, Sakarya.

Toulmin, C., \& Quan, J. (2000). Evolving land rights, policy and tenure in Africa. London: DFID/IIED/NRI.

Tunkham, P., Donpudsa, S., \& Dornbundit, P. (2016). Development of STEM activities in chemistry on "protein" to enhance 21 st century learning skills for senior high school students, Silpakorn University Journal of Social Sciences, Humanities, and Arts, 16(3), 217-234.

TÜSİAD, (2017). Faaliyet raporu [Activity report]. https://tusiad.org/tr/faaliyetraporlari/item/9911-tusiad-faaliyet-raporu-2017

Walker, J. P., Sampson, V., Grooms, J., Anderson, B., \& Zimmerman, C. O. (2012). Argument-driveninquiry in undergraduatechemistrylabs: theimpact on students' conceptualunderstanding, argumentskills, andattitudestowardscience, Journal of CollegeScienceTeaching, 41(4), 74. 
Webb, D. (2013). STEM Lesson Essentials, Grades 3-8: integrating Science, Technology, Engineering, and Mathematics, Teacher Education and Practice, 26(2), 358-364.

Yamak, H., Bulut, N., \& Dündar, S. (2014). The impact of stem activities on 5th grade students' scientific process skills and their attitudes towards science, Gazi University Journal of Gazi Educational Faculty, 34(2), 341-744.

Yavuz, M., Hasancebi , M., \& Yesildag-Hasancebi,F. (2020). The effect of STEM application on 21st-century skills of middle school students and student experiences. Journal of Soft Computing and Artificial Intelligence , 1(1), 29-41.

Yesildag-Hasancebi, F., \& Gunel, M. (2014). Delving into the effect of argumentation based inquiry approach on learning science from multiple perspectives. Journal of Research in Education and Society, 1(1), 23-44.

Yıldırım, A., \& Şimşek, H. (2000). Sosyal Bilimlerde Nitel Araştırma Yöntemleri [Qualitative research methods in the social sciences]. Ankara: Seçkin Publishing.

Yildırım, B., \& Altun, Y. (2015). Investigating the Effect of STEM Education and Engineering Applications on Science Laboratory Lectures. El-Cezerî Journal of Science and Engineering, 2(2), 28-40.

Y1lmazçelik, E. (2020). The effect of argumentation method on the academic achievement and attitude of science teacher candidates in 'Genetic copying' unit. (Unpublished master thesis), Süleyman Demirel University: Isparta.

Zhou, M. (2010). Chinatown: The socioeconomic potential of an urban enclave. Temple University Press.

Zoller, U. (1993). Lecture and learning: Are they compatible? Maybe for LOCS; Unlikely for HOCS, Journal of Chemical Education, 70(3), 195-197. 